\title{
Vegetative multiplication of date palms from in vitro cultured inflorescences: effect of some growth regulator combinations and organogenetic potential of various cultivars
}

\author{
Kenza Loutfi ${ }^{\mathrm{a}, \mathrm{b} *}$, Hassan Chlyah ${ }^{\mathrm{c}}$ \\ ${ }^{\natural}$ Laboratoire de physiologie végétale, département de biologie, faculté des sciences Semlalia, B.P. S 15, Marrakech, Morocco

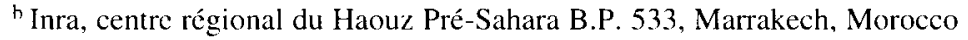 \\ " Laboratoire de physiologie végétale, faculté des sciences, B.P. 1014, Rabat, Morocco
}

(Received 16 March 1998; accepted 24 July 1998)

\begin{abstract}
Explants from inflorescences of date palms from different female cultivars and one selected male clone were cultured on five growth regulator combinations. Shoot primordia formed mostly on Greshoff and Doy media containing: $0.5 \mathrm{mg} \mathrm{L}^{-1}$ of naphthalene acetic acid (NAA), $2 \mathrm{mg} \mathrm{L}^{-1}$ of 6-benzylaminopurine (BA) and I $\mathrm{mg} \mathrm{L}^{-1}$ of 2-isopentyladenine (2iP). Shoot multiplication occurred on the same medium, but plant growth and rooting were only obtained by a tenfold reduction in cytokinin concentration or by an increase in NAA to $2 \mathrm{mg} \mathrm{L}^{-1}$ in combination with $1 \mathrm{mg} \mathrm{L}^{-1} 2 \mathrm{iP}$ or $1 \mathrm{mg} \mathrm{L}^{-1} \mathrm{BA}$. Histological analysis of cultured explants revealed that buds originated from petal primordia. Percentages of reactive inflorescence explants in various media differed among cultivars examined. The technique offers great promise for vegetative propagation of date palms since several hundred plants could be obtained from a single inflorescence, and each individual tree can produce several inflorescences annually. ( $\odot$ Inra/Elsevier, Paris.)
\end{abstract}

micropropagation / Phoenix dactylifera L. / organogenesis / female and male inflorescences

Résumé - Multiplication végétative du palmier dattier à partir de segments d'inflorescences cultivés in vitro : effet de différentes combinaisons hormonales et capacités organogénétiques de divers cultivars. Des fragments d'inflorescences appartenant à différents cultivars femelles de palmier dattier et à un clone mâle sélectionné ont été mis en culture in vitro en présence de cinq combinaisons hormonales différentes. La formation des bourgeons et leur multiplication étaient meilleures sur le milieu Greshoff et Doy en presence de $0,5 \mathrm{mg} \mathrm{L}^{-1}$ d'acide naphtylacétique (ANA), $2 \mathrm{mg} \mathrm{L}^{-1}$ de 6-benzylaminopurine (BAP) et $1 \mathrm{mg} \mathrm{L}^{-1}$ de 2- isopentyladénine (IPA). Cependant la régénération de plantules entières n'a été obtenue qu'après réduction des teneurs en cytokinines ou augmentation des teneurs en ANA à $2 \mathrm{mg} \mathrm{L}^{-1}$ en com-

Communicated by Georges Pelletier (Versailles, France)

* Correspondence and reprints

Fax: (212) 04.43.74.12 
binaison avec $1 \mathrm{mg} \mathrm{L}^{-1}$ d' IPA ou de BAP. Des coupes histologiques réalisées à différents moments de culture ont montré que les bourgeons sont initiés à partir des pétales en multiplication. Des différences entre les cultivars téstés ont été observées en ce qui concerne les pourcentages de réactivité dans différents milieux de culture. Cette technique est très prometteuse pour la multiplication de l'espèce du fait que des centaines de plantes peuvent être obtenues à partir d'une seule inflorescence et que chaque pied de palmier dattier peut fournir plusieurs inflorescences par an. (@) Inra/Elsevier, Paris.)

micropropagation / Phoenix dactylifera L. / organogenèse / inflorescences / femelles et mâles

\section{INTRODUCTION}

For some years the vegetative multiplication of date palm by in vitro culture has been the subject of numerous studies [5, 9, 19, 22-24]. In most cases the cultured explants were taken from young tissues of basal offshoots. Use of inflorescences as starting material has been rarely described $[3,8]$, and the technique is still not sufficiently developed to be used by plant breeders.

In Morocco, an important date palm breeding programme was initiated by the Institut national de la recherche agronomique (Inra) in the early 1970s. The ultimate goal of the project was to restore date palm groves devastated by the bayoud disease caused by an imperfect fungus, Fusarium oxysporum f. sp. albedinis. This pathogen threatened to destroy important date palm groves in Morocco and Algeria. The development of an appropriate and convenient means of propagation of this species is therefore the key to the success of the whole date palm programme.

Up to this point the tissue culture programme has made use of offshoots since it is a most convenient starting material; however, the availability of such offshoots constitutes a limiting factor. Indeed, in cases where selected clones are represented by only one tree, only a small number of offshoots will be available ( $0-3$ offshoots per year). The possible use of inflorescences in such cases is therefore an attractive alternative since a single tree can produce ten inflorescences per year composed of hundreds of flower buds that can be used as explants.

The objective of the present study is to define the best experimental conditions suitable for the induc- tion of shoot formation and the regeneration of plants from various cultivars.

\section{MATERIALS AND METHODS}

\section{1. Plant material}

All inflorescences were collected in the experimental station Nebch in Zagora (south Morocco). The following female cultivars were used in this study: Ademmou, Aguellid, Ahardane, Boufegous, Bouittoub, Bousthammi noire, Iklane, Jihel, Mejhoul and Tadment (native to the main Moroccan groves) and Deglet nour and khouatftimi (native to Tunisia). Those cultivars were chosen for their resistance to bayoud disease and/or date quality. The principal characters of each of them were reported by Saaidi $[20,21]$. Sair 1 and Sair 2 are Fl hybrids (from unknown parental cultivars) selected at the experimental station for their resistance to bayoud and visually identified as different genotypes. Inflorescences, which were still enclosed in their spaths (sheets), were collected during the flowering period (end of February to end of April). The samples were maintained at $8{ }^{\circ} \mathrm{C}$ until used. Male inflorescences originating from a male clone (NP3, Inra ) selected in the same field as female cultivars were sampled from the beginning of January to the end of February. Spaths $<25 \mathrm{~cm}$ long were cleaned with alcohol and surface sterilized with $9 \%$ sodium hypochlorite solution supplemented with $200 \mathrm{mg} \mathrm{L}^{-1}$ potassium permanganate. Spaths $>25 \mathrm{~cm}$ were first dipped in a suspension of fungicide powder (Mancozan $4 \mathrm{~g} \mathrm{~L}^{-1}$ ) for $10 \mathrm{~min}$ and cut open under aseptic conditions. Sodium hypochlorite $\left(6^{\circ}\right)$ was then administered as a disinfectant to floral explants for $20 \mathrm{~min}$. These explants were then dipped three times in sterile distilled water. Segments about $5 \mathrm{~mm}$ long with approximately $2-3$ closed flower buds were cut and inoculated in test tubes. 


\subsection{In vitro culture}

Three different culture media were used in succession: a starting medium, then a multiplication medium on which shoots became visible and multiplicated, and a plant growth and rooting medium. A study was carried out for each stage of culture to determine the best growth regulator combinations. The basal medium contained macro- and micronutrients [11], iron chelate [15] and various additives (in $\mathrm{mg} \mathrm{L}^{-1}$ ): 0.3 nicotinic acid, 0.01 thiamine $\mathrm{HCl}, 0.01$ biotine, 2 glycine, 200 to 250 tyrosine (in the starting medium) or 100 glutamine (in the following media, so as to avoid formed shoots and callus being left too long in the tyrosine medium, which is a risk for browning of tissues), 100 inositol, 40000 sucrose, 2000 polyvinylpyrrolidone, 8000 agar-agar or carragheenan. Five combinations of NAA, BA and $2 \mathrm{iP}$, chosen after preliminary experiments were used in the starting medium: $\mathrm{C} 1\left(0.5 \mathrm{mg} \mathrm{L}^{-1} \mathrm{NAA}\right.$ and $0.1 \mathrm{mg} \mathrm{L}^{-1}$ BA), C2 (0.5 $\mathrm{mg} \mathrm{L}^{-1} \mathrm{NAA}$ and $\left.3 \mathrm{mg} \mathrm{L}^{-1} \mathrm{BA}\right), \mathrm{C} 3$ ( $1 \mathrm{mg}$ $\mathrm{L}^{-1} \mathrm{NAA}$ and $\left.0.1 \mathrm{mg} \mathrm{L}^{-1} \mathrm{BA}\right), \mathrm{C} 4\left(1 \mathrm{mg} \mathrm{L}^{-1} \mathrm{NAA}\right.$ and 1 $\left.\mathrm{mg} \mathrm{L}^{-1} \mathrm{BA}\right)$, C5 (0.5 $\mathrm{mg} \mathrm{L}^{-1} \mathrm{NAA}, 2 \mathrm{mg} \mathrm{L}^{-1} \mathrm{BA}$ and 1 $\mathrm{mg} \mathrm{L}^{-1} 2 \mathrm{iP}$ ). The $\mathrm{pH}$ of the media was adjusted to $5.8 \pm$ 0.1 with $\mathrm{HCl}$ or $\mathrm{NaOH}$ solutions. All media were dispensed as $25-\mathrm{mL}$ aliquots into $25 \times 150 \mathrm{~mm}$ culture tubes, which were then capped with polycarbonate lids and autoclaved for $20 \mathrm{~min}$ at $118^{\circ} \mathrm{C}$. Cultures were initially incubated in the dark for 3-6 months, sometimes more, at $28{ }^{\circ} \mathrm{C}$. Subculturing onto fresh medium was carried out every 4-6 weeks. Data concerning the tissue growth were recorded at each subculture. Reactive cultures (specially with multiplicated floral pieces and/or initiated shoots) obtained from any starting medium were subcultered on a multiplication medium containing (in $\mathrm{mg} \mathrm{L}^{-1}$ ) $0.5 \mathrm{NAA}, 1$ or $2 \mathrm{BA}$, and $12 \mathrm{iP}$; $0.5 \mathrm{NAA}$, $0.2 \mathrm{BA}$ and $0.12 \mathrm{iP}$ or $0.5 \mathrm{NAA}$ and $0.12 \mathrm{iP}$ and transferred to diffuse light until shoots developed and became green. They were then incubated under a 16-h day length at $28^{\circ} \mathrm{C}$. Light was provided by cool fluorescent bulbs at $180 \mu \mathrm{E} \mathrm{m}^{-2} \mathrm{~s}^{-1}$. Shoots are lastly subcultured on a plant growth and rooting medium containing (in $\mathrm{mg} \mathrm{L}^{-1}$ ) 2 NAA and 1 BA or 2 NAA and $12 \mathrm{iP}$. The developed plantlets were planted in a mixture of peat and sand $(1: 1)$ and grown in a greenhouse. Analysis of variance (ANOVA) and Newmann and Keuls test (significance level: $P=0.05$ ) were used for multiple comparisons of means from the treatments.

\section{3. Histological analysis}

For histological observations explants were fixed in FAA (formalin-acetic acid-ethanol, 5:5:90, V/V/V) solution. They were dehydrated in series of increasing concentrations of ethanol, embedded in paraffin and sectioned at $8-10 \mu \mathrm{m}$ thick. Sections were then stained with hematoxylin.

\section{RESULTS}

\subsection{Floral explant effects}

The developmental stage of inflorescences was shown to be a very important factor in the evolution of the cultures taken from it. Very young female inflorescences (enclosed by spaths $<6 \mathrm{~cm}$ long) did not react in the presence of all combinations tested. Young inflorescences (enclosed by spaths of $10-25 \mathrm{~cm}$ in length bearing mature flowers $0.2-1.5 \mathrm{~mm}$ long), started to form roots (figure l), callus (figure 2) or new floral organs (figure 3) after 2 months of culture. No shoot formation was observed before at least 4 months. Old inflorescences (enclosed by spaths $25-50 \mathrm{~cm}$ in length bearing mature flowers $2-4 \mathrm{~mm}$ long) reacted $2-3$ months later and showed a limited capacity for shoot formation (table I). Moreover, they tended to grow unlimited roots even in cytokinin-rich media (e.g. C2 or C5). For male inflorescences two categories were distinguished: young ones with spaths $10-20 \mathrm{~cm}$ long and old ones with spaths $20-40 \mathrm{~cm}$ long, both with mature flowers. Young male inflorescences need 2-3 months of culture to respond with callus or shoot formation (table I). Old ones do not grow or differentiate any formations at all. Statistical analyses of all data given in table $I$ revealed a high significant effect of the inflorescence age on the percentage of explants bearing shoots or callus. Young inflorescences were more reactive than older $\left(\mathrm{F}_{1,20}=153.44\right.$ and $\mathrm{F}_{1,20}=$ 118.57 for shoot and callus production, respectively). The sex of inflorescences also influenced in vitro response. Female inflorescences were significantly superior for shoot regeneration $\left(\mathrm{F}_{1,20}=\right.$ $55.58)$ and callus production $\left(\mathrm{F}_{1,20}=19.34\right)$ than male inflorescences. In most cases (for female and for male inflorescences) multiplication of floral parts: petals, carpels or stamens took place before 


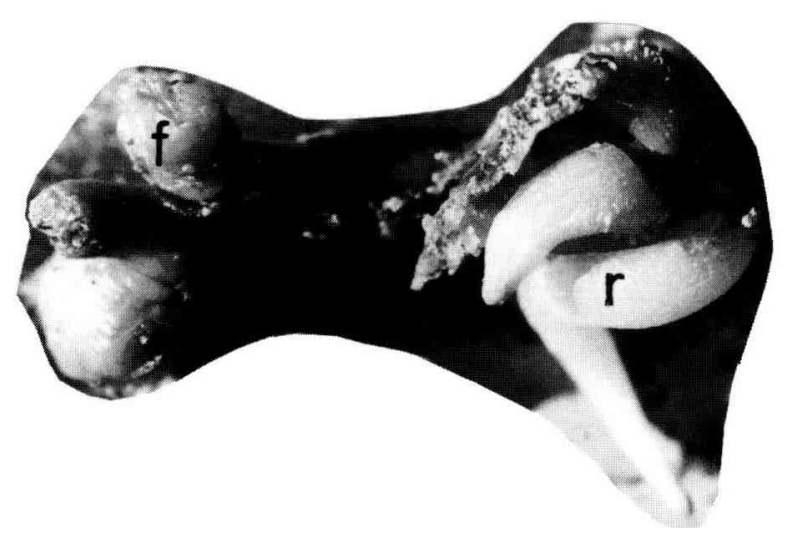

Figure 1. Inflorescence segment with initiation of roots from the basal region of a female flower (cultivar Tadment ). $r=$ root, $f^{\prime}=$ flower.

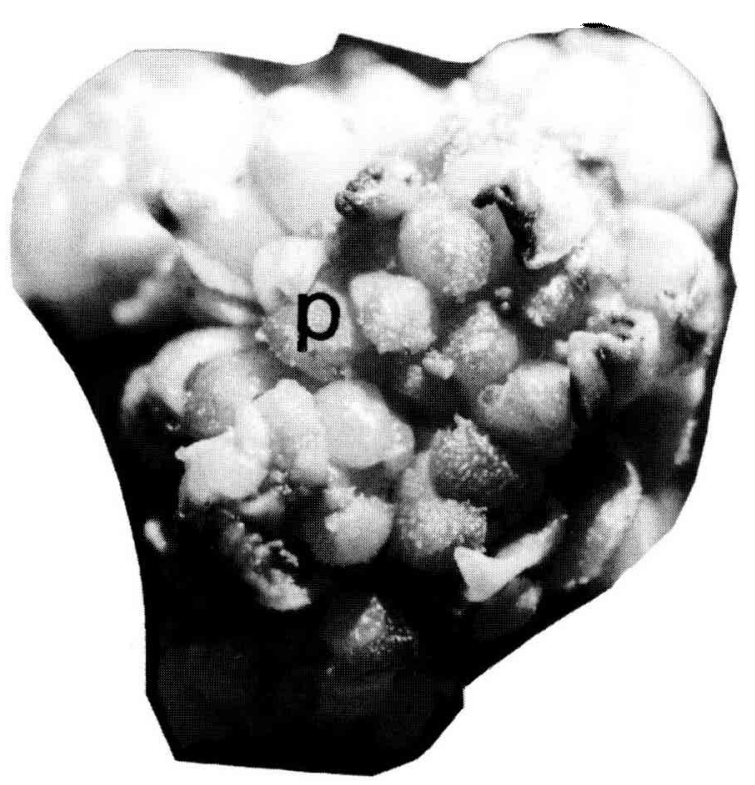

Figure 3. Segment of a female inflorescence (cultivar Iklane) that is cultured on C5 medium for 4 months. Note that numerous petals are formed. $\mathrm{p}=$ petals.

bud initiation. At this stage, thin sections of developed parts revealed that shoots initiated from petals that were formed de novo (figure 4) without an intermediate callus phase (data not shown). Sepals, carpels and stamens became brown and degenerated.

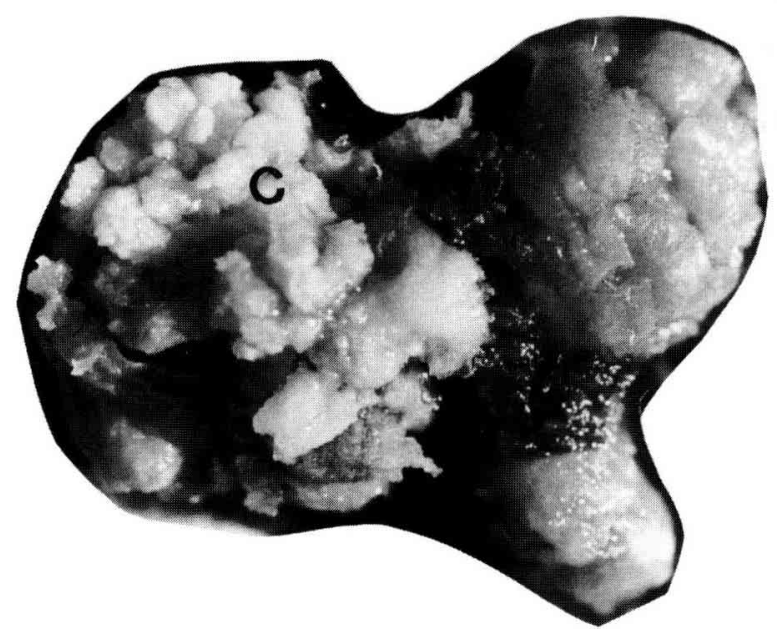

Figure 2. Callus formation from female flower pieces (cultivar Iklane) on $\mathrm{Cl}$ combination. $\mathrm{c}=$ callus.

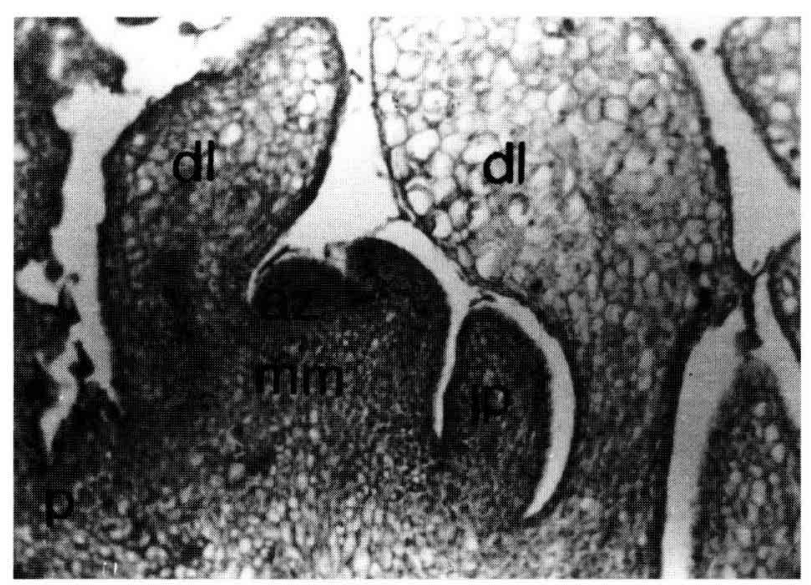

Figure 4. Histological section of a female petal (cultivar Iklane) with shoot initiation $(\times 4000)$. az $=$ apical zone, $\mathrm{mm}=$ medullary meristem, $\mathrm{l} p=$ leaf primordium, $\mathrm{dl}=$ developed leaf primordium, $\mathrm{p}=$ petal.

\subsection{Effects of growth regulators}

A significant influence of growth regulator combinations on the percentages of explants bearing shoots $\left(F_{4.20}=139.80\right)$ or callus $\left(F_{4.20}=13.42\right)$ was 
Table I. Influence of growth regulator combinations on shoot and callus formation from male (clone NP3) and female (cultivar Iklane) date palm inflorescences after 8 months of culture.

\begin{tabular}{|c|c|c|c|c|c|c|}
\hline \multirow{2}{*}{$\begin{array}{l}\text { Growth regulator } \\
\text { combinations }\end{array}$} & \multicolumn{3}{|c|}{$\%$ of explants producing shoots } & \multicolumn{3}{|c|}{$\%$ of explants producing callus } \\
\hline & Young male & Young female & Old female & Young male & Young female & Old female \\
\hline $\mathrm{Cl}$ & $0^{d}$ & $0^{d}$ & $0^{\mathrm{d}}$ & $35^{a}$ & $9^{b}$ & 3 bed \\
\hline $\mathrm{C} 2$ & $6^{c}$ & $5^{c}$ & $3^{c}$ & 3 hed & 4 bed & 3 bed \\
\hline $\mathrm{C} 3$ & $0^{d}$ & $0^{\mathrm{d}}$ & $0^{d}$ & 4 hed & $29^{a}$ & 3 bcd \\
\hline $\mathrm{C} 4$ & $0^{\mathrm{d}}$ & $6^{c}$ & $3^{c}$ & 3 bod & 4 bcd & 5 bc \\
\hline C5 & $27^{\mathrm{b}}$ & $35^{\mathrm{a}}$ & $5^{\mathrm{c}}$ & $6^{b c}$ & $1^{\mathrm{cd}}$ & $4^{\text {bcd }}$ \\
\hline
\end{tabular}

38-40 explants are used for each combination and percentages are calculated from two replications.

Analysis on data was carried out after arcsin transformation; non-transformed data are presented.

Percentages with the same letters are not significantly different at $5 \%$ level.

observed. The $\mathrm{Cl}$ and $\mathrm{C} 3$ media were favourable for callus formation (table I), whereas the C5 medium characterized by a low auxin to cytokinin ratio induced bud formation either directly or after multiplication of floral parts. The positive effect of the C5 combination on shoot development was particularly evident for young male and young female inflorescences. Calli initiated on $\mathrm{Cl}, \mathrm{C} 3$ or $\mathrm{C} 4$ media produced mostly root meristems or became brown and degenerated if they were not subcultured on a medium rich in cytokinins. Shoot regenerations were obtained from these calli after transfer to the $\mathrm{C} 5$ combination.

\subsection{Effect of cultivar variability}

Explants from 14 female cultivars were grown on C5 (favourable combination) medium. Statistical analysis of their responses revealed a hierarchy of cultivars for the frequency of shoot production with Deglet Nour then Ademmou, Boufegous and Sair 1 being significantly superior, in comparison to the others $\left(\mathrm{F}_{13,14}=5.45\right)$. Thus, we can distinguish groups of cultivars that behave similarly with regard to shoot initiation (table $I I$ ). Callus formation was weak for all tested cultivars on this combination of growth regulators as previously observed, without significant differences $\left(\mathrm{F}_{13,14}=0.85\right)$.
Table II. Effect of cultivar variability on the percentage of explants from female inflorescences (enclosed by spaths $25-30 \mathrm{~cm}$ long) producing shoots or callus after 8 months of culture on C5 medium.

\begin{tabular}{lcc}
\hline \multirow{2}{*}{ Cultivars } & \multicolumn{2}{c}{$\%$ of explants producing: } \\
\cline { 2 - 3 } & shoots & callus \\
\hline Ademmou & $2^{\text {ab }}$ & $0 \mathrm{~ns}$ \\
Aguellid & $5^{\mathrm{bc}}$ & $0 \mathrm{~ns}$ \\
Ahardane & $5^{\mathrm{bc}}$ & $0 \mathrm{~ns}$ \\
Boufegous & $19^{\mathrm{ab}}$ & $3 \mathrm{~ns}$ \\
Bouittoub & $5^{\mathrm{bc}}$ & $2 \mathrm{~ns}$ \\
Bousthammi noire & $3^{\mathrm{c}}$ & $0 \mathrm{~ns}$ \\
Deglet nour & $2^{\mathrm{a}}$ & $5 \mathrm{~ns}$ \\
Iklane & $5^{\mathrm{bc}}$ & $5 \mathrm{~ns}$ \\
Jihel & $10^{\mathrm{abc}}$ & $0 \mathrm{~ns}$ \\
Khouatftimi & $5^{\mathrm{bc}}$ & $0 \mathrm{~ns}$ \\
Mejhoul & $5^{\mathrm{hc}}$ & $2 \mathrm{~ns}$ \\
Sair 1 & $1^{\mathrm{ab}}$ & $3 \mathrm{~ns}$ \\
Sair 2 & $9^{\mathrm{abc}}$ & $3 \mathrm{~ns}$ \\
Tadment & $2^{\mathrm{c}}$ & $2 \mathrm{~ns}$ \\
\end{tabular}

20-22 explants are used for each cultivar and percentages are calculated from two replications. Analysis on data was carried out after arcsin transformation; non-transformed data are presented. Percentages followed by the same letters are not significantly different at $5 \%$ level, ns = non-significant difference.

\section{Shoot multiplication}

Shoots initiated directly from floral parts were transferred to light for further growth. Shoot growth and multiplication were evident when they were 
Table III. Influence of some growth regulator combinations on the multiplication index* of shoots obtained from inflorescences of four female cultivars (Aguellid, Bouittoub, lklane, Tadment) and a male clone (NP3).

\begin{tabular}{lccccc}
\hline $\begin{array}{l}\text { Growth regulators } \\
\text { concentrations }\left(\mathrm{mg} \mathrm{L}^{-1}\right)\end{array}$ & Aguellid & Bouittoub & Iklane & Tadment & NP3 \\
\hline NAA, 0.5; BA, 0.1;2iP, 0 & $1.56^{\mathrm{c}} \pm 0.30$ & $1.41^{\mathrm{c}} \pm 0.26$ & $1.08^{\mathrm{c}} \pm 0.08$ & $1.08^{\mathrm{c}} \pm 0.08$ & $1.07^{\mathrm{c}} \pm 0.04$ \\
NAA, 0.5; BA, 0.2; 2iP, 0.1 & $1.35^{\mathrm{c}} \pm 0.02$ & $1.46^{\mathrm{c}} \pm 0.13$ & $1.14^{\mathrm{c}} \pm 0.24$ & $2.43^{\mathrm{b}} \pm 0.05$ & $1.14^{\mathrm{c}} \pm 0.11$ \\
NAA, 0.5; BA, 2; 2iP, 1 & $2.21^{\mathrm{b}} \pm 0.59$ & $2.66^{\mathrm{b}} \pm 0.29$ & $1.26^{\mathrm{c}} \pm 0.03$ & $3.18^{\mathrm{a}} \pm 0.32$ & $1.22^{\mathrm{c}} \pm 0.60$ \\
\hline
\end{tabular}

* Multiplication index (= number of cultures suitable for multiplication obtained within 6 weeks/number of initial cultures) were calculated from three replications per treatment. Each treatment contains initially $37-40$ cultures.

subcultured on a medium containing: $0.5 \mathrm{mg} \mathrm{L}^{-1}$ NAA, 1 or $2 \mathrm{mg} \mathrm{L}^{-1} \mathrm{BA}$ and $1 \mathrm{mg} \mathrm{L}^{-1} 2 \mathrm{iP}$ first under low intensity of light, then incubated under a 16-h photoperiod of $180 \mu \mathrm{E} \mathrm{m}^{-2} \mathrm{~s}^{-1}$ (figure 5). The multiplication index calculated within 6 weeks for several female cultivars and a male clone was dependent on growth regulator combinations $\left(\mathrm{F}_{2.30}\right.$ $=39.90)$. The best index was obtained with $0.5 \mathrm{mg}$ $\mathrm{L}^{-1} \mathrm{NAA}, 2 \mathrm{mg} \mathrm{L}^{-1} \mathrm{BA}$ and $1 \mathrm{mg} \mathrm{L}^{-1} 2 \mathrm{iP}$ (table III), but significant differences between tested cultivars for shoot multiplication capacity were observed $\left(\mathrm{F}_{4}\right.$ ${ }_{30}=19.72$ ). Tadment then Bouittob and Aguellid were superior to Iklane and the male clone NP3.

\subsection{Plant development}

Multiplication media with low concentrations of cytokinins, e.g. $0.5 \mathrm{mg} \mathrm{L}^{-1} \mathrm{NAA}$ and $0.1 \mathrm{mg} \mathrm{L}^{-1}$ $\mathrm{BA}$, or $0.5 \mathrm{mg} \mathrm{L}^{-1} \mathrm{NAA}, 0.2 \mathrm{mg} \mathrm{L}^{-1} \mathrm{BA}$ and $0.1 \mathrm{mg}$ $\mathrm{L}^{-1} 2 \mathrm{iP}$ ) allowed good shoot individualization and subsequent growth to plantlets, but it required 8-10 subcultures (9-11 months) to obtain $50 \%$ of enlarged and rooted shoots. Consequently they were replaced by media with high concentrations of auxins containing: $2 \mathrm{mg} \mathrm{L}^{-1} \mathrm{NAA}$ with $1 \mathrm{mg} \mathrm{L}^{-1}$ $\mathrm{BA}$ or $2 \mathrm{mg} \mathrm{L}^{-1} \mathrm{NAA}$ with $1 \mathrm{mg} \mathrm{L}^{-1} 2 \mathrm{iP}$ to stimulate plants growth and rooting. After four subcultures (5-6 months) percentage of enlarged and rooted shoots (now plants) was 60 and $20 \%$ in the first and the second growth regulator combinations, respectively. Well-developed vitroplants were obtained through this technique and after weaning

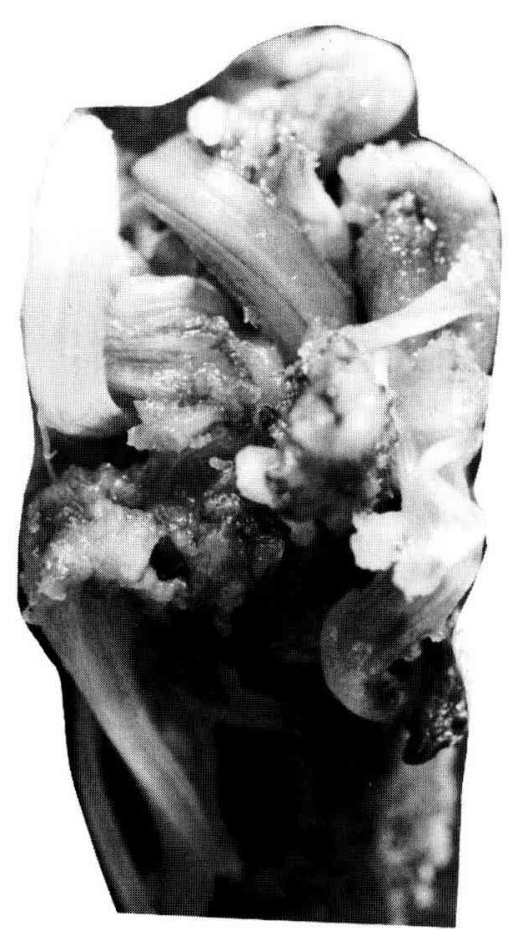

Figure 5. Multiplication of date palm shoots initiated from a female inflorescence segment (cultivar Iklane) on C5 combination of growth regulators.

to soil in greenhouse showed apparently normal phenotypes, after several months of growth.

\section{DISCUSSION AND CONCLUSIONS}

The positive effect on shoot formation of the C5 medium, characterized by a low auxin to cytokinin 
ratio, was observed for young male and young female inflorescences. These results show that date palm floral explants used in this study behave differently from offshoot tissues for which a medium rich in auxin is more favourable for inducing bud formation and tissue development [2, 7, 17]. Differences between floral and vegetative explants in endogenous hormone contents and their accumulation and sensitivity to exogenous hormones could explain these different requirements. Relationships between endogenous hormone levels of cultured explants and morphogenetic responses have been recently studied for other systems $[12,16]$.

Growth regulator combinations with $0.5 \mathrm{mg} \mathrm{L}^{-1}$ $\mathrm{NAA}, 1 \mathrm{mg} \mathrm{L}^{-1}$ or $2 \mathrm{mg} \mathrm{L}^{-1} \mathrm{BA}$ and $1 \mathrm{mg} \mathrm{L}^{-1} 2 \mathrm{iP}$ are optimal for shoot multiplication. Development of multiplicated shoots in plantlets can occur if the concentrations of cytokinins are reduced (e.g. ten times), but it necessitates many months of subculture. Thus, the best development of plantlets was accomplished with increased concentrations of NAA. The positive effect of NAA on date palm tissue cultures has been reported earlier $[14,26]$. On the same medium the shoot regeneration and callus formation capacity of floral explants varied with genotype. Some cultivars are superior to others. Beauchesne [1] observed that each date palm cultivar needs a modification of growth regulator combinations to optimize responses. The importance of genotype effect on in vitro response of cultured inflorescences $[10,13,25]$ and other tissues $[4,6$, 18] has been reported in several species. In this study we can distinguish groups of cultivars that behave similarly with regard to the percentages of shoots and callus production. It will be very interesting to define the best growth regulator combinations for each group in order to optimize responses from floral explants of date palm.

Histological analysis of differentiating floral explants has shown that shoot primordia initiated directly from petals while carpels and stamens degenerated. Using very young female inflorescences (4-6 weeks before their rise), Drira and Benbadis [8] obtained vegetative buds from carpels that reversed from the reproductive to the vegetative phase. This difference in morphogenetic behaviour may be attributed to the age of inflorescences and/or the experimental conditions. There was no visible somaclonal variability in regenerated plants. However, the plants obtained through this technique must be followed for several years in order to analyse whether or not they are true-to-type. Organogenesis from male and female date palm inflorescences may offer a new possibility for mass multiplication of this species. Use of mature inflorescences makes this technique easy and does not affect the mother tree during the collection of plant material. It is possible to obtain more than 100 explants from a single spath and each tree can produce up to ten spaths. This technique could therefore be used in breeding programmes for the multiplication of selected date palm plants or cultivars for which no offshoots or a limited number of them are available and could take part in breeding programmes which aim to restore date palm groves devastated by pathogen disease.

Acknowledgements: We thank Dr G. Beauchesne (member of the French Academy of Agriculture) for valuable discussions and advice about date palm tissue culture, Dr E.A. Ameziane (Inra, Station centrale d'agronomie Saharienne) and Dr B. Chlyah for their helpful criticism.

\section{REFERENCES}

[1] Beauchesne G., Vegetative propagation of date palm Phoenix dactylifera by in vitro culture, Date palm symposium, Al hassa, Arabia Saoudia, 1982.

[2] Beauchesne G., Zaid A., Rhiss A., The meristematic potential of bottom of young leaves to rapidly propagate date palm, 2 nd Int. Congress on date palm, Arabia Saoudia, 1986.

[3] Bhaskaran S., Smith R., Somatic embryogenesis from shoot tip and immature inflorescences of Phoenix dactylifera CV. Barhee, Plant Cell Rep. 12 (1992) $22-25$.

[4] Bianchi S., Flament P., Dattée Y., Embryogenèse somatique et organogenèse in vitro chez la luzerne : évaluation des potentialités de divers génotypes, Agronomie 8 (2) (1988) 121-126.

[5] Bouguedoura N., Michaux-Ferriere N., Bompar JL., Comportement in vitro de bourgeons axillaires de 
type indeterminé du palmier-dattier (Phoenix dactylifera), Can. J. Bot. 68 (1990) 2004-2009.

[6] Chambon C., Poupet A., Beck D., Bettachini B., Touche J., Capacités de morphogenèse in vitro de divers clones de lavandes et lavandins : observations préliminaires sur la valeur agronomique des vitroplants, Agronomie 12 (1992) 173-181.

[7] Drira N., Multiplication végétative du palmier-dattier (Phoenix dactylifera L.) par la culture in vitro de bourgeons axillaires et de feuilles qui en dérivent, C. R. Acad. Sci., Paris 296 (1983) 1077-1081.

[8] Drira N., Benbadis A., Multiplication végétative du palmier-dattier (Phoenix dactylifera L.) par réversion en culture in vitro d'ébauches florales de pieds femelles, J. Plant. Physiol. 119 (1985) 227-235.

[9] El hadrami I., Cheikh R., Baaziz M., Somatic embryogenesis and plant regeneration from shoot-tip explants in Phoenix dactylifera L., Biologia Plantarum 37 (1995) 205-211.

[10] Frett J., Dirr MA., Tissue culture propagation of Liriope muscari and Ophiopogon jaburan, Hort. Sci. 18 (4) (1983) 431-432.

[11] Gresshoff PM., Doy CH., Development and differentiation of haploid Lycopersicon esculentum (tomato), Planta 107 (1972) 161-170.

[12] Julliard J., Étude de l'aptitude à la régénération chez Brassica napus L. var. oleifera : influence du genotype et de la transformation par le T(L)-DNA d'Agrobacterium rhizogénes ; relations avec le metabolisme hormonal, thèse, Université de Paris, 1992, 307 p.

[13] Malaure R.S., Barclay G., Power J.B., Davey M.R., The production of novel plants from florets of Chrysanthemum morifolium using tissue culture 1. Shoot regeneration from Ray florets and somaclonal variation exhibited by the regenerated plants, J. Plant Physiol. 139 (1991) 8-13.

[14] Mater A.A., In vitro propagation of Phoenix dactylifera L., Date Palm J. 4 (2) (1986) 137-152.
[15] Murashige T., Skoog F., A revised medium for rapid growth and bioassays with tissue cultures, Physiol. Plant. 15 (1962) 473-497.

[16] Perrin Y., Doumas P., Lardet I., Carron MP., Endogenous cytokinins as biochemical markers of rubber-tree (Hevea brasiliensis) clone rejuvenation, Plant Cell Tissue and Organ Culture 47 (3) (1996) 39-245.

[17] Poulain C., Rhiss A., Beauchesne G., Multiplication végétative en culture in vitro du palmier dattier (Phoenix dactylifera), C. R. Acad. Agr. Fr. 65 (13) (1979) 1115-1154.

[18] Radice S., Caso OH., Somatic embryogenesis and organogenesis in cultured cotyledons of Silybum marianum (L.) Gaertn, Biocell 21 (1) (1997) 59-64.

[19] Reuveni O., Adata Y., Lilien-Kipnis H., A study of new and rapid methods for the vegetative propagation of date palms, Date Growers Inst. Rept. 49 (1972) $16-24$.

[20] Saaidi M., Contribution à la lutte contre le bayoud, fusariose vasculaire du palmier dattier, thèse, Université de Dijon, 1979, 140 p.

[21] Saaidi M., Comportement au champ de 32 cultivars de palmier dattier vis-à-vis du bayoud : 25 années d'observations, Agronomie 12 (1992) 359-370.

[22] Schroeder CA., Tissue culture of date shoots and seedlings, Date Growers Inst. Rept. 47 (1970) 25-27.

[23] Sharma D.R., Deepak S., Chowdhyry J.B., Regeneration of plantlets from somatic tissues of the date palm (Phoenix dactylifera L), Ind. J. Exp. Bot. 24 (1986) 763-766.

[24] Tisserat B., Foster G., DeMason D., Plantlet production in vitro from Phoenix dactylifera $L$., Date Growers Inst. Rept. 54 (1979) 19-23.

[25] Vasil I.K., Developing cell and tissue culture systems for the improvement of cereal and crass crops, J. Plant Physiol. 128 (1986) 193-218.

[26] Zaid A., Tisserat B., In vitro shoot tip differentiation in Phoenix dactylifera L., Date palm J. 2 (2) (1983) $163-182$. 